\title{
韓国大邱市邑城区域における都市型韓屋の維持・転用の現状と住民意識 に関する考察

\author{
HABITANTS' CONSCIOUSNESS AND CURRENT CONDITION OF \\ URBAN TRADITIONAL HOUSE IN THE OLD CASTLE DISTRICT, \\ DAEGU, KOREA
}

\author{
羅 羽 哲*, 阿部 浩 和** \\ Woochul NA and Hirokazu ABE
}

\begin{abstract}
There were many historical buildings and Urban Traditional Houses in the downtown of Daegu where had been established in the old castle district in 1737. Recently, more Urban Traditional Houses have been disappearing by the progress of urbanization and modern life style in Daegu. This paper will examine the current condition of the Urban Traditional Houses including converted one, and it will identify the habitants' perception for conservation or development of the houses and townscape in the old castle district of Daegu. The results are as follows. 1) The number of family member in $75 \%$ of the houses is three and below. And the age of $67 \%$ householder is sixty years old or more in this area. 2) Some remaining Korean houses in Jingorumok Area are split type of houses which were large Urban Traditional Houses constructed before 1920. 3) Regarding the rooms and equipments of Urban Traditional Houses, the level of satisfaction of almost inhabitants living there is very low. In contrast, regarding the townscape, the level of satisfaction of almost habitants living or working there is relatively high. 4) Many habitants living in the Urban Traditional House are adverse to the conservation of this area. However, Many shop owners using the Urban Traditional House are agree with the conservation of this area.
\end{abstract}

Keywords : Urban Traditional House, Habitants'Consciousness, Daegu, Conversion, Conservation 都市型韓屋，住民意識，大邱市，転用，維持

\section{1. 序}

\section{1 研究の背景と目的}

韓国の大邱市は、朝鮮半島の東南部に位置しており、中心市街地 は、1737 年に建設された邑城注 1）を中心に形成され、歴史的建築物 が数多く存在している。その中には、朝鮮時代末期以降に建てられ た都市型韓屋も現存している。しかしながらそれらは近年の都市開 発や生活様式の変化によって急速に消失してきており、わずかに残 る都市型韓屋も現在では居住者の減少とともに店舗や食堂などに転 用されるケースも見られ、建物の老朽化や周辺地区の居住環境の悪 化などが進んでいる注2)。また、細街路に面した地域の防犯、防災 対策なども課題になっており注 3 )、都市型韓屋の保全を含めた抜本 的な地域整備が必要な状況である。

一方、韓国ではこれまで慶洲市、全州市およびソウル市などにお いて都市美観地区指定や韓屋登録制などによる都市型韓屋の保存施 策が実施され ${ }^{3)}$ 、現在では多くの観光客を集めている4 ${ }^{4)}$ これまで 保存政策を実施してこなかった大邱市においてもこのような旧市街 地に残る都市型韓屋群を含む街路景観の価值が見直され 5)、その保
全、活用への関心が高まってきている。

本研究では、将来の大邱市邑城区域における市街地整備に関わる 都市型韓屋の保全、活用の可能性を探るための手がかりを得ること を目的として大邱市邑城区域内にわずかに残る都市型韓屋が現在ど のように維持、転用されているのかの実態を把握し、当該韓屋居住 （使用）者の住環境意識を明らかにするものとする。

\section{2 都市型韓屋の定義}

「韓屋」とは韓国様式の伝統木造住宅のことで、中でも「伝統韓屋」 は主として高麗時代（918 年）から朝鮮時代までの士大夫、両班（王 族および貴族）が生活していた木造瓦莫の住宅を意味する場合が多 い6)。一方、「近代韓屋」は、Yoon JaeWoong ${ }^{7)}$ によれば開化期 (1876 年）注4) 以後から日帝時代注5) にかけて郊外に建設された「伝統改 良韓屋」で、当時の生活様式の変化に対応したものとしている。ま た、Ha JaeMyung ${ }^{8)}$ によれば 1930 年前後から 1960 年頃までに都 心部およびその周辺地域に建設された中小規模の韓屋群が一般的に 「改良韓屋」と呼ばれているとしており、これまでの「伝統韓屋」が
$*$ 大阪大学大学院工学研究科 博士後期課程 $\cdot$ 修士 (建築学)

** 大阪大学サイバーメディアセンター 教授・工博
Ph. D. Candidate, Graduate School of Eng., Osaka University, M. Arch. Prof., Cyber Media Center, Osaka University, Dr. Eng. 
改良され新しい機能と生活様式の変化によって建設されたものと述 べている。また、Song $\mathrm{InHo}^{9)}$ は、「都市型韓屋」をこれまでの「伝 統韓屋」が都市住居地のなかで適応された住宅形態として定義して おり、Park CheolJin ${ }^{10)}$ も 1930 年代にソウル市北村地区などに新 しく建設された「改良韓屋」を「都市型韓屋」として扱っている。 ただ、同時代の旧市街地内においても、韓国様式の木造瓦莫家屋が 建設されており、それらは必ずしも「改良韓屋」だけではないこと から、本論文では、「都市型韓屋」を朝鮮時代末期から日帝時代、朝 鮮戦争時代を経て 1980 年代頃注6) までに都心部において建設され た韓国様式の木造瓦莫家屋と定義して以下の研究を行う。

\section{3 既往の研究}

都市型韓屋の平面形態に関する既往の研究は、「嘉会洞韓屋保存地 区実測調查報告書 (ソウル市) 」 ${ }^{11}$ や Song InHo ${ }^{12}$ ) の研究があり、

Sohn SeiKwan ${ }^{13)}$ は全州市における 1940 年代から 1980 年代まで の都市型韓屋の類型分析を行っている。また、大邱市に関しては Ha JaeMyung ${ }^{8)}$ が邑城区域外の西城洞、仁橋洞地区において 1930 年から 1960 年に建設された韓屋の調査を行い、その空間構成をア ンチェ注 7) と付属建物で構成された配置形式によって 5 種類に分類 し、ソウル市や全州市の代表的な類型との違いを明らかにしている。 また、都市型韓屋の変容に関して Song $\mathrm{InHo}^{14}$ ) はソウル市北村 地区において韓屋の増改築の状況について分析しているが、これら は保存地区内の案内所や文化施設など観光目的施設への改修の状況 を扱っており、保存施策を実施してこなかった大邱市とは背景が異 なる。また、大邱市においては Ha JaeMyung ${ }^{15)}$ が西城洞におけ る敷地細分化や都市型韓屋の増改築状況を調查しているが、店舗な どへの転用については扱っておらず、韓屋居住（使用）者の維持と 住環境意識について分析しているわけではない。

一方、近年の大邱市における都市型韓屋を含む住宅建替えに関し て、槙鮮化ら ${ }^{16)}$ は大邱市三徳洞地区を取り上げ、1997 年から 2004 年の間で約 3 割の家屋が建て変わっていること、従前とは異なり多 世帯が居住する小規模共同住宅（多口家）が増加し、屋外空間の形 態が変化していることなど明らかにしている。また、Yeo $\mathrm{MiNa}^{1}{ }^{17}$ は、大邱市周辺部に位置する住宅地を対象として緑地環境に対する 居住者認識と緑地空間構成および利用実態を把握し居住環境の改善 について分析している。ただ、これらの研究はいずれも大邱市邑城 区域外に造成された地域を対象としており、慶尚監営注8) からの旧 市街地である邑城区域内における都市型韓屋の実態についての研究 は稀少である。また、1995 1996 年に実施された Ha JaeMyung ${ }^{8)}$ 15) の調查以降 15 年が経過し、現在では都市型韓屋の多くが急速 に消失しており、僅かに残る都市型韓屋も居住者が減少し、この地 域において他の用途に転用された韓屋の実態を分析する研究も稀少 である。本論文では、大邱市邑城区域内（城内一洞～城内三洞）に 残存する都市型韓屋を Ha JaeMyung ${ }^{8}$ ) が示した邑城区域外の西城 洞、仁橋洞地区における韓屋類型と比較するとともに、その維持と 転用の実態および韓屋居住（使用）者の住環境意識を明らかにする ものとする。

\section{4 大邱邑城の歴史}

大邱市は、2010 年時点で人口が約 250 万人、面積 $884.16 \mathrm{~km}^{2} 、$ 韓
国第三の広域都市である。大邱市は、1601 年（宣宗 34 年）に慶尚 道の監営が設置され、嶺南地方注9) の行政、軍事の中心地として発 展し、1737 年に邑城城壁が建設された。しかし、1905 年の京釜(ソ ウルと釜山)線鉄道開通とともに大邱駅舎が邑城の北門外側に建設 され、1906 年に日本の居留民団による邑城の撤去が行われた。その 後、邑城城壁があった場所には四城路（東城路、西城路、南城路、 北城路）が建設され、南城路から大邱駅舎までを南北に縦断する中 央通が 1917 年に建設された。1910年からの日韓合併後、邑城区域 外の西城路、東城路の区域整理が行われ、韓国人居住地が建設され て邑城内の既存居住者の強制移住が行われた ${ }^{8)}$ 。以後、邑城区域内 は、国債報償路などの幹線道路建設や地下鉄の整備、細街路の拡幅 工事などとともに布政洞と東城路 2 街の民間再開発が行われ市街化 が進んでいる。

\section{2. 調査方法の概要}

本研究では、大邱市邑城区域(城内一洞〜城内三洞)にわずかに残 る都市型韓屋が現在どのように維持、転用されているのかの実態を 明らかにし、そこでの住環境意識を把握することを目的に以下の調 查分析を実施した。

(1)邑城区域に残存寸る都市型韓屋の把握と調査対象の選定

文献資料と実踏調査を元に邑城区域に現存する都市型韓屋を把握 し、調査対象を選定するとともに、その位置づけを確認した。（第 1 次調查 : 2009.9.7 11.22)

(2)都市型韓屋の現場詳細調查（現場調查）

対象韓屋の建築形状、建築様式、建築年度および構造材料、増改 築の状況を現場調査した。（第 2 次調查 : 2010.4.7〜 5.6)

(3)韓屋類型の確認と増改築の分析

既往研究 ${ }^{8)}$ における韓屋類型と比較するとともに、維持、転用に 伴う増改築状況を分析した。

(4)都市型韓屋の居住(使用)者へのアンケート調査

韓屋をそのまま住宅として維持使用している居住者および店舗な ぞ他の用途に転用している使用者に対して韓屋の維持、転用の履歴 と居住環境、周辺環境についての意識調査を実施した。（第 2 次調 查: $2010.4 .7 \sim 5.6$ )

\section{3. 結果と考察}

\section{1 邑城区域内に残存する都市型韓屋の把握と調査対象の選定}

大邱市作成の建物現況図 (2009 年) および大邱市発行の航空写真 （2009 年）を元に邑城区域内に残る木造瓦莫家屋 82 件を把握し、 現地での実踏調査によって現在の邑城区域内に残存する都市型韓屋 50 件（住居以外の用途に転用されているものも含む）を特定した注 10)。図 1 にその分布現況および建物番号を示寸。現存する都市型 韓屋は、邑城区域の南側と北西側（鐘路 1 街、鐘路 2 街、南城路、 寿洞、西門路 1 街、西内洞、北内洞など）に残っているが、北東側 と東側部分は既に開発が進んでおり、都市型韓屋は残っていない。

邑城区域内に現存する都市型韓屋 50 件の使用用途の現況を表 1 に示寸。これを見ると、住居専用として使用されているのが 23 件 $(46 \%)$ であり、商業専用 9 件 $(18 \%)$ 、住居と商業の併用（以下、 住商併用）が 10 件 $(20 \%)$ 、空き家 8 件（16\%）であった。以下で は、このうち協力が得られた 32 件 $(64 \%)$ を調査対象として、居 
住（使用）者へのアンケート調査を実施し、その内 27 件 $(54 \%)$ については当該韓屋の現場調查を行う。

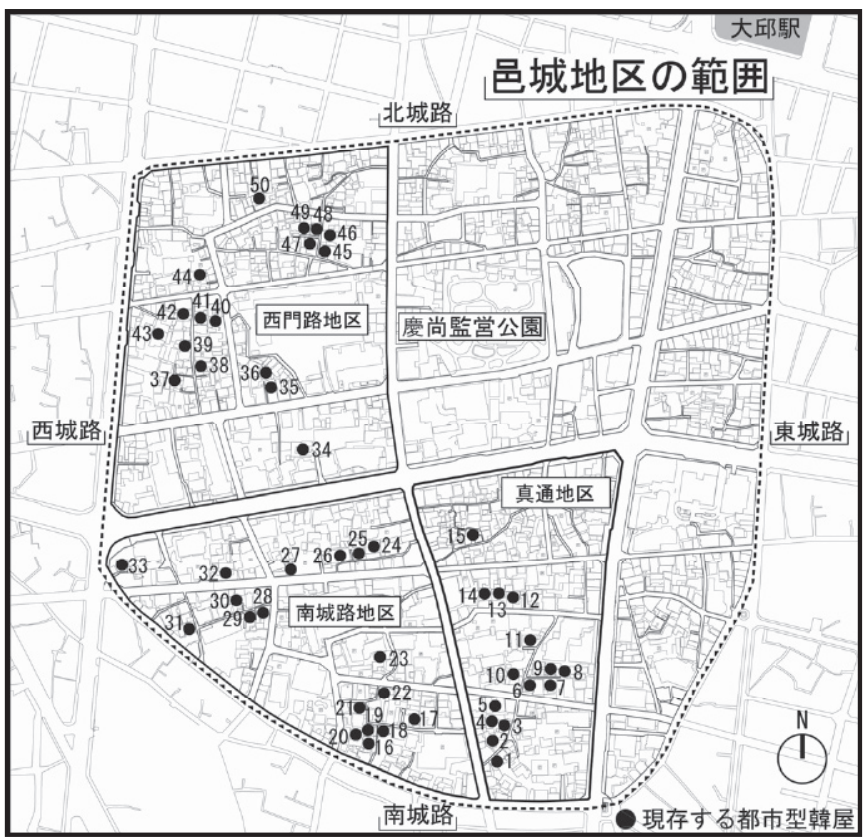

図 1 邑城区域内における都市型韓屋の分布現況および建物番号 (大邱市作成の建物現況図 2009 年より作成)

表 1 調査対象

\begin{tabular}{|c|c|c|c|c|c|}
\hline 区分 & 住居専用 & 商業専用 & 住商併用 & 空家 & 計 \\
\hline 都市型韓屋の総数 & 23 & 9 & 10 & 8 & 50 \\
\hline アンケート対象 & 15 & 8 & 9 & 0 & 32 \\
\hline 現場調査対象 & 10 & 8 & 9 & 0 & 27 \\
\hline
\end{tabular}

ここで全 50 件の都市型韓屋の敷地面積と建築面積の分布を図 2 に示す。敷地面積、建築面積については大邱市発行の地籍図および 建物の登記簿を元に算出した。これによると敷地面積の範囲は 49.6 $\mathrm{m}^{2} \sim 979.8 \mathrm{~m}^{2}$ 、建築面積については $34.6 \mathrm{~m}^{2} \sim 344.1 \mathrm{~m}^{2}$ 、邑城区域 内の残存寸る韓屋 50 件に対して、現場調査を行った韓屋 27 件の分 布傾向はほぼ同様である。また、敷地面積の平均值は全体（50 件） で $260.1 \mathrm{~m}^{2}$ 、現場調查韓屋（27 件）で $238.1 \mathrm{~m}^{2}$ 、建築面積の平均值 は全体（50 件）で $113.8 \mathrm{~m}^{2}$ 、現場調查韓屋（27 件）で $104.6 \mathrm{~m}^{2}$ で あり、それぞれの平均值の間に $5 \%$ 水準の有意差注 11 1) は見られなか った。したがってここで選定した現場調查韓屋は邑城区域内に残存 する韓屋とほぼ同様であると判断して以下の分析を行う。

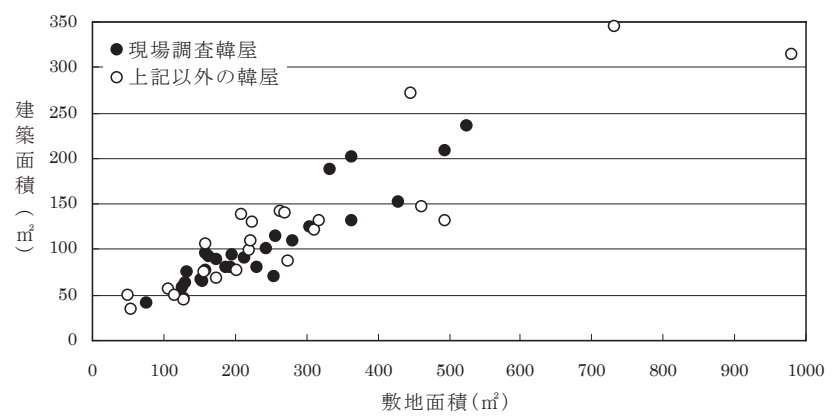

図 2 残存する都市型韓屋の敷地面積と建築面積の分布現況 $(\mathrm{N}: 50)$

\section{2 現場調査結果の概要}

表 2 に現場調查を行った都市型韓屋 27 件の調查結果を示す。各 建物の平面図注 $12 ）$ と室名は現在の使用状況を示寸もので、灰色部 分は建設後に増築された部分を示している。また、それぞれに建築 年度、増築年度、敷地面積、延べ床面積、増築面積、使用用途、平 面類型（3.6 で詳述する）を示す。ここで増築部分の特定は現地調 查、建物の登記簿、文献資料18）19）抢よび現在の居住（使用）者 への聞き取り調查によって判断した。

まず、はじめに現場調查を行った 27 件の韓屋のうち店舗に転用 されている韓屋と住宅として維持されている韓屋の事例 2 件につい て、その調査概要を以下に示す。

\section{店舗に転用されている韓屋（No.1）}

図 3 にNo.1 について現在の平面図を示寸。この建物は、1965 年 に住宅として建設されたが、1994 年に現在の所有者が購入して増改 築を行い、現在は商業専用用途（食堂）で使用している。

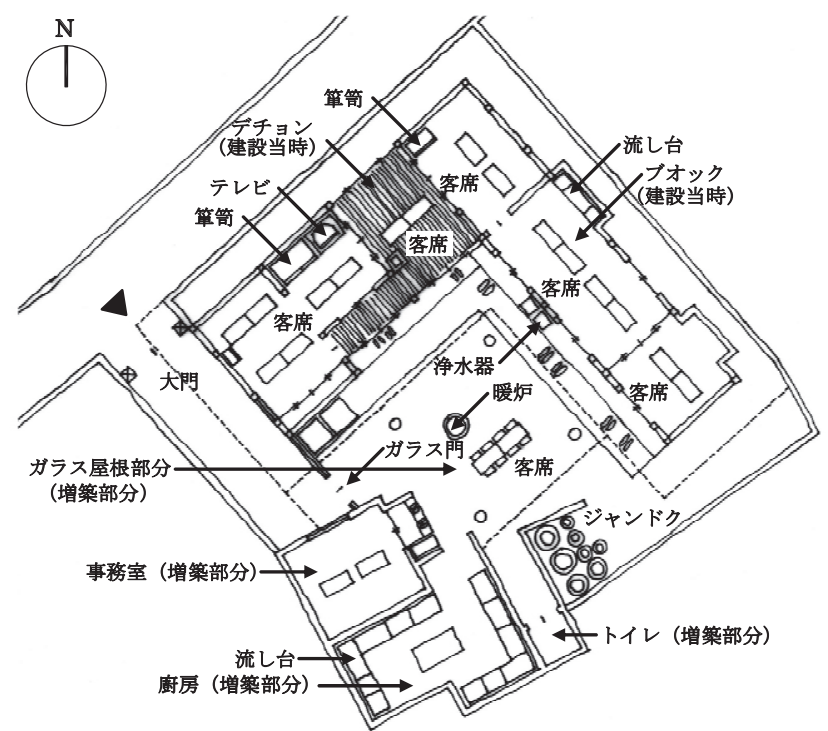

図 3 No.1 韓屋の図面注 131

敷地面積は $183.1 \mathrm{~m}^{2}$ 、延べ床面積 $115.8 \mathrm{~m}^{2}$ で、商業転用面積 115.8 $\mathrm{m}^{2}$ 、商業増築面積 $49.7 \mathrm{~m}^{2}$ である。なお、建物の大門注 14) は西側に あり、南側に廻って当該建物に入ることになる。増改築前の建物の 平面は L 字型であり、屋根はパルジャック屋根注 1 5) (入母屋屋根)、 小屋組みは 3 樑注 1 5) で、デチョン注16) は南東向きである。

建物の保存状態は非常に良いが、店舗に転用寸るに当たって部屋 の間仕切りを取り除いて既存のブオック注 17 ) 部分も床を上げて客 席に利用している。また、マダン注 18$)$ の南側には店舗用に㕌房と トイレおよび事務室が増築されている。また、2007 年には再度、増 改築が行われ、㕑房と客席の床、暖房設備の改修とともにマダン部 分にガラス屋根が設置され、店舗客席として使用している。

\section{住宅として維持されている韓屋(No.18)}

図 4 に No.18 について現在の平面図を示す。この建物は、1961 年に現居住者が住宅として建設し、現在も住宅として維持されてい る。敷地面積は $224.2 \mathrm{~m}^{2}$ 、延べ床面積 $74.0 \mathrm{~m}^{2}$ で元の住宅部分の床面

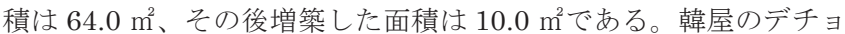


表 2 現場調査対象韓屋の一覧注 121

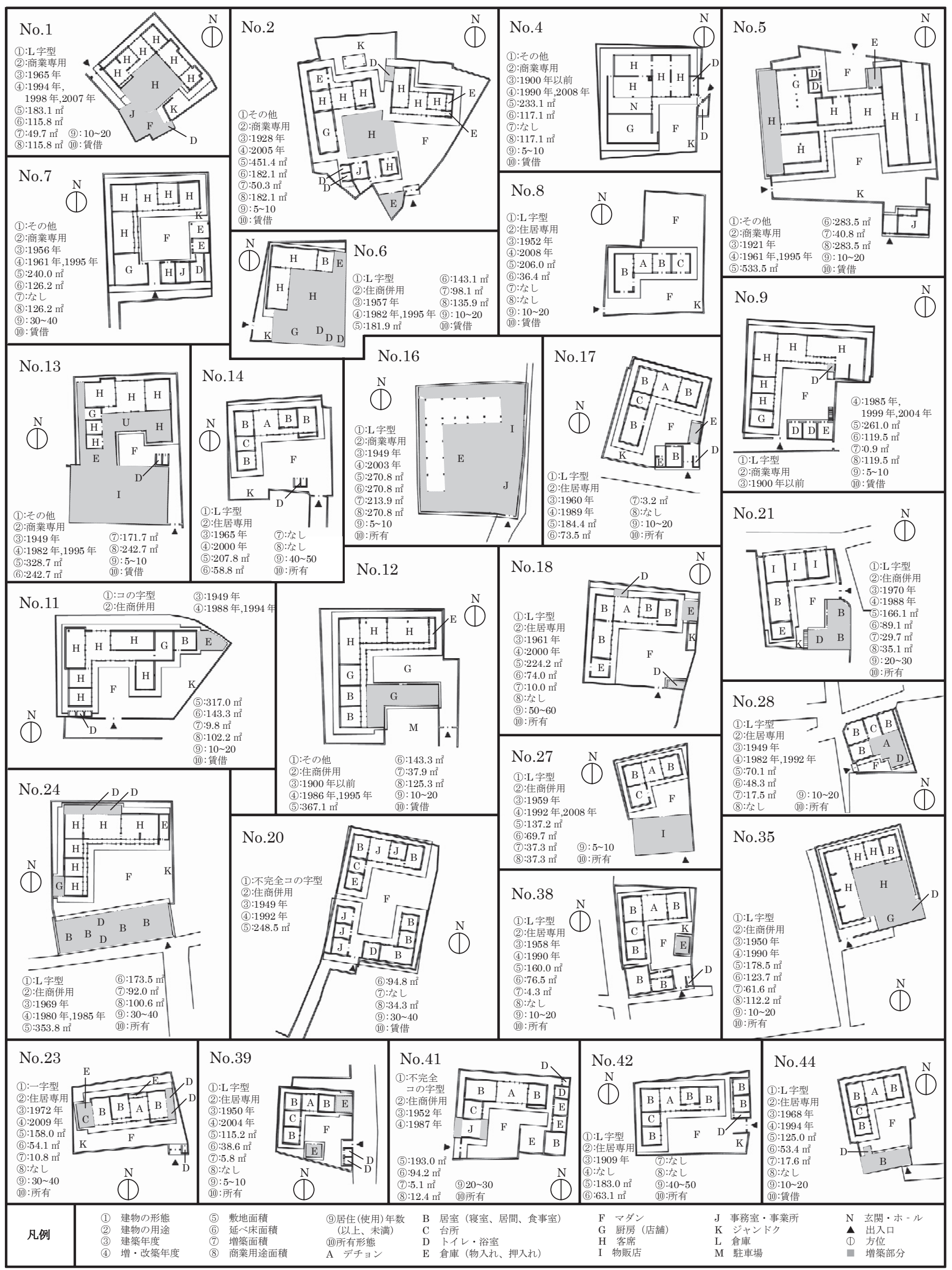


ンは南側に向いている。建物の平面形態は L 字型であり、屋根はパ ルジャック屋根、小屋組みは 3 樑である。建設当時、家族構成は、 夫婦、息子二人、娘二人の 6 人が居住し、食事は夏はデチョン、冬 はアンバン注19)でそれぞれ行われており、大門は西側にあった。

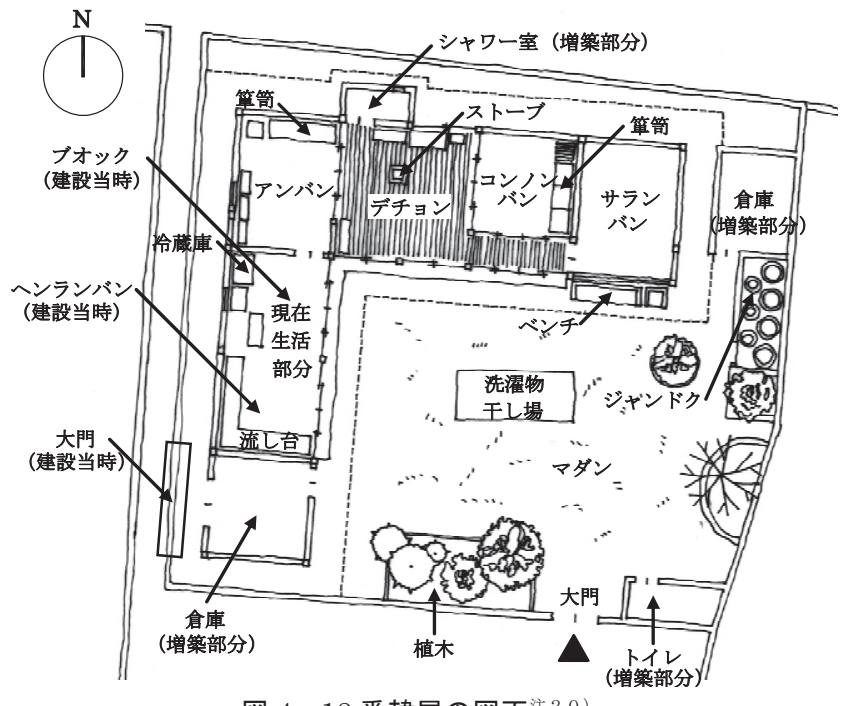

図 418 番韓屋の図面注 20

当時の部屋の使用状況は、アンバンを主人の夫婦が使用し、コン ノンバン注 2 1) は娘二人、サランバン注 22 2) は息子二人、ヘンランバ ン注2 3) は家政婦が使用していた。暖房方式はオンドル注 24) でブオ ックの床レベルは地面より低く、デチョンの床レベルは地面より約 $45 \mathrm{~cm}$ 高く設定されていた。その後、2000 年に増改築が行われ、へ ンランバンの南側とジャンドク注 25) の隣に倉庫が増築され、西側 にあった大門は南側に移設された。また、デチョンの後ろにシャワ 一室が増築され、隙間風を防ぐためにデチョンの開口部や空にアル ミサッシが設置された。その後、子供は独立し、家族人数が減少し て、多くの部屋は不要となり、以前のブオックとヘンランバンの間 の壁を撤去した部分で生活をするようになった。現在は、他の部屋 （アンバン、デチョン、コンノンバン、サランバン）は使用しておら ず、所有者が一人で居住し維持管理をしている。

\section{3 都市型韓屋の居住 (使用) 者の状況}

アンケート調查対象韓屋における使用用途別の居住 (使用) 年数、 所有区分、継承形態の割合を図 5、6 に示す。

これをみると、商業専用の場合の使用年数は 10 年未満が約 $60 \%$ （5 件）で 20 年未満は $87 \%$ （7 件）を占めているのに対して、住居 専用と住商併用の場合は 10 年以上が約 $85 \%$ （21 件）であり、特に 住居専用では 30 年以上の居住者が約 $40 \%$ （6 件）を占めている。 また、商業専用の場合は賃借の割合が約 9 割（7 件）と高く、住居 専用の場合は所有の割合が 8 割（12 件）と高い。また、建物の継承 形態は多くが現在の居住(使用)者の世代からであったが、住居専用 では父母世代から継承されたものが約半数を占めている。

以上のことから商業に転用されている韓屋の 8 割（7 件）が 1990 年代以降（約 20 年以内）に事業者が韓屋の所有者から建物を借り て営業していること、一方住宅として維持されている韓屋の約半数 （7 件）は父母世代から継承されており、現居住者の約 4 割（8件） が 30 年以上ここに居住していることが分かった。

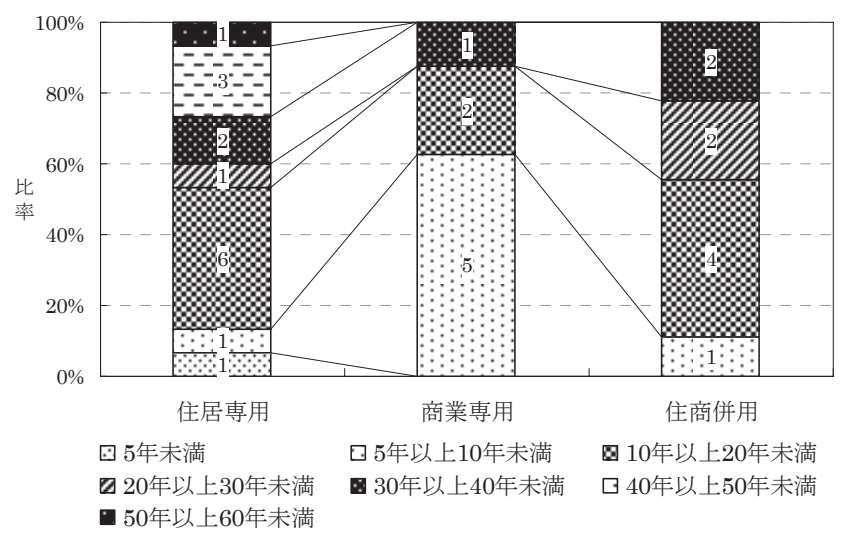

図 5 都市型韓屋の居住年数 $(\mathrm{N}: 32)$
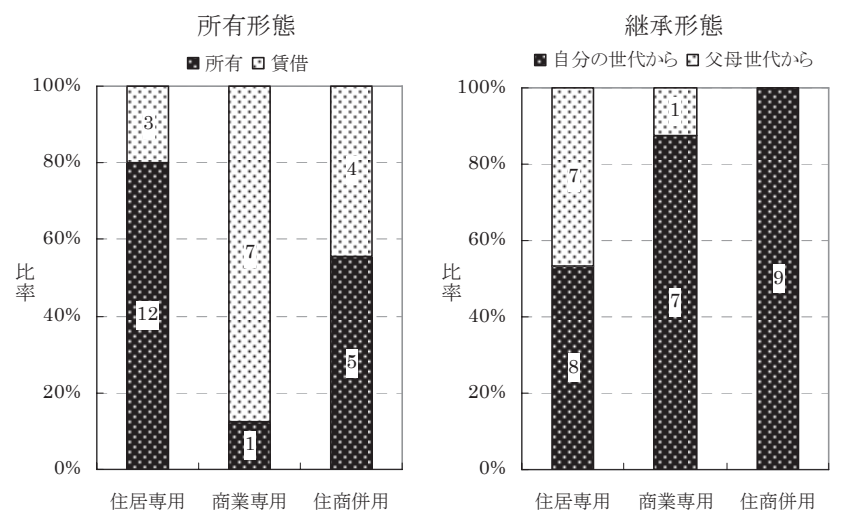

図 6 都市型韓屋の所有区分と継承形態の割合 $(\mathrm{N}: 32)$
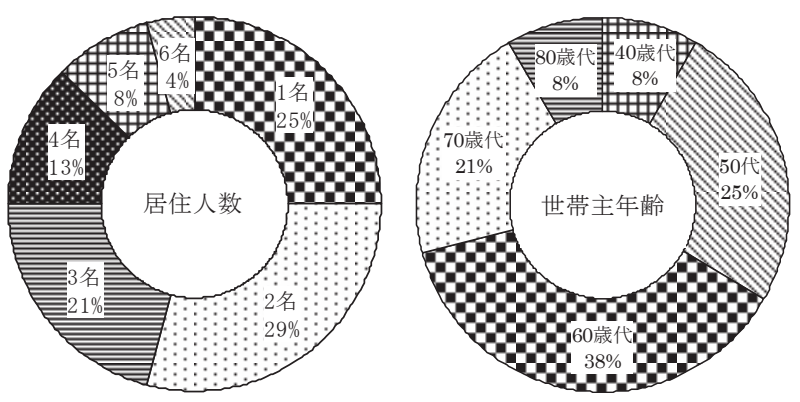

図 7 都市型韓屋の居住人数と世帯主年齢の割合 $(\mathrm{N}: 24)$

次に、住宅として使用されている韓屋 24 件（居住専用と住商併 用）における家族人数と世帯主の年齢の割合を図 7 に示す。 1 人暮 らしの世帯が 4 分の 1 であり、家族人数が 3 人以下の家族も約 $75 \%$ （18 件）を占めている。また、世帯主の年齢は 60 歳代以上が約 $67 \%$ （16 件）を占めており、住宅として使用されている韓屋においては 所有者が居住している割合が高く家族の少人数化、高龃化の傾向が 示唆される。

\section{4 韓屋の用途別面積}

図 8 に現場調査対象韓屋の延べ床面積とそれに占める商業増築面 積、商業転用面積（元の韓屋の転用部分）、住宅増築面積、残存住居 面積（元の韓屋を住居のまま使っている部分）を示す。

これを見ると、延べ床面積は真通地区がその他地域に比べて大き く、増築を除く既存韓屋部分の床面積は真通地区の平均が約 $104 \mathrm{~m}^{2}$ 、 南城路地区約 $59 \mathrm{~m}^{2}$ 、西門路地区は約 $59 \mathrm{~m}^{2}$ であった。また、商業転 
用部分があるほとんどの韓屋は真通地区に分布している一方、南城 路地区や西門路地区では住宅のまま維持されている韓屋が多い注 2 6)

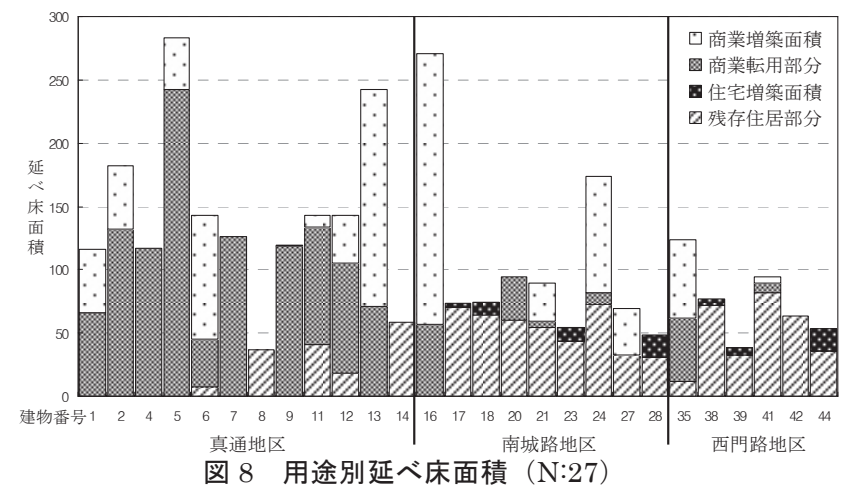

\section{5 建設年度と増改築年度}

図 9 に現場調查対象韓屋の建設年度と増改築年度を示寸。それぞ れの年度については上棟樑注 2 7) に記載されている年度と建物の登 記簿、文献資料 18）１9）を元に決定した注28)（建設年代○、増改築 年代を(0で示す)。

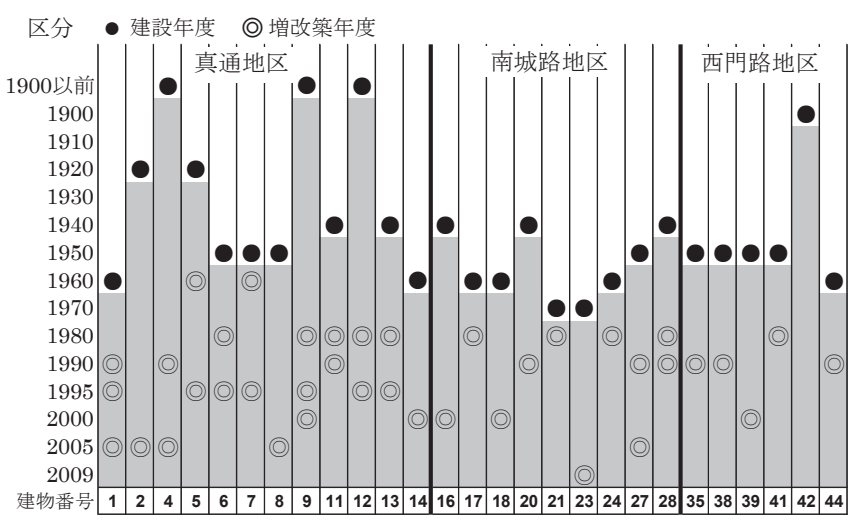

図 9 建設年度と増改築年度 $(\mathrm{N}: 27)$

これによると、現存する韓屋は 1900 年以前から建てられ始め、 1945 年〜1960 年の間に最も多く建てられ (19 件)、1910 年〜1945 年の日帝時代には、真通地区で 2 件が建設されている。

また、増改築については、1980 年代 10 件 $(26 \%) 、 1990$ 年代 16 件 $(41 \%) 、 2000$ 年代 11 件（28\%）である。

以上のことから大邱市邑城区域内の韓屋は日帝時代が終わった 1945 年以降に多くの都市型韓屋が建設され、1980 年代からの急速 な都市化とともに増改築、転用が増えたものと考えられる。

\section{6 邑城区域における韓屋の平面類型と増改築の分析}

これまで大邱市における都市型韓屋の平面類型に関する研究とし ては、Ha JaeMyung ${ }^{8)}$ が 1996 年に邑城区域外の西城洞、仁橋洞地 区における都市型韓屋の調查を行い、その平面類型をアンチェと付 属建物で構成された全体の配置形態によって一字型、L 字型、不完 全 L 字型、コの字型、不完全コの字型の 5 種類注 29$)$ に分類してい る。

本論文においてもこの類型を基本に分析を行い、これらの類型と 異なる場合は「その他」に分類し別途検討を行うものとする。なお、
調查対象とした韓屋は維持、転用の過程で増改築が行われているた め、増改築前の状況を推定して分類を行った上で、増改築された部 分についての分析を行う。なお、増改築前の推定の方法は現地調查、 建物の登記簿、文献資料 18）１9）および居住（使用）者への聞き取 り調查などから判断した。また、増改築の分析に関しては、既存建 物に続けて増築されたものを「連続増築」、分離して増築されたもの を「別棟増築」、中庭部分が室内化されたものを「マダン増築」とし、 部屋の用途変更に伴って既存家屋の内装を変更したものを「内部改 修」として、複数の事象がある場合は重複を認めて集計した。

表 3 に調查対象韓屋の類型と増改築の分析結果を示す。これによ れば、 $\mathrm{L}$ 字型が 17 件で最も多く、コの字型が 1 件、不完全コの字 型注29) が 2 件、一字型が 1 件で、「その他」が 6 件であった。この うち L 字型は 3 つの地区に分散して見られるが、「その他」に分類 された韓屋はすべて真通地区に見られる。また、増改築については 「連続増築」が 14 件、「別棟増築」が 13 件、「マダン増築」が 4 件、 「内部改修」は 23 件であり、「連続増築」はほとんどの類型に見ら れるが、「別棟増築」は L 字型と「その他」だけに見られ「マダン 増築」は商業用途だけに見られる。また、事例の中で増築のパター ンが二つ以上重なる No11、No23 などは、「連続増築」と「内部改 修」の両方を実施していることになる。

表 3 韓屋の類型注 29 )

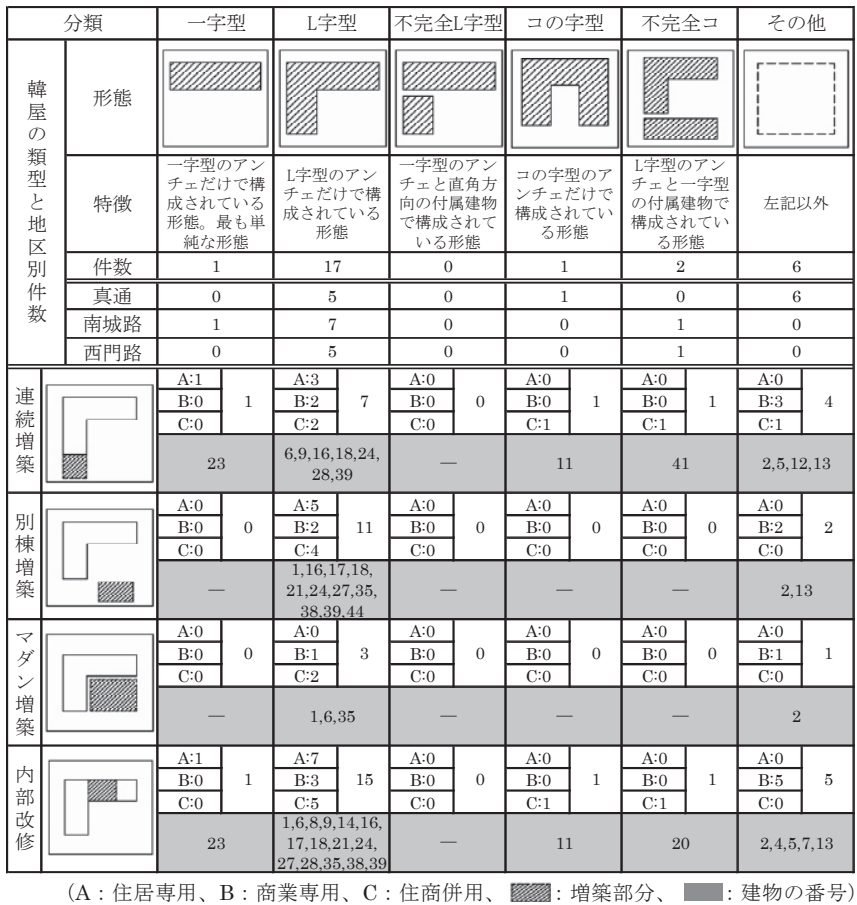

次に、「その他」に分類された韓屋について考察を行う。

\section{その他の韓屋 1（No.2、No.4、No.5）}

No.2 は、現在商業専用（食堂）として使用されているが、伝統韓 屋の空間構成 20 ）であるアンチェ、サランチェ注３０）、ンランチェ 注 31 ）などの各々の建物が全体を構成している。ただ、各々の建物 が持つマダンは見られない 19$)$ 。No.4 も現在は商業専用（食堂）と して使用されており、その平面形態は一見 $\mathrm{L}$ 字型であるが、内部構 
成は Ha JaeMyung ${ }^{8)}$ が示した L 字型韓屋と異なる玄関が室内にあ り、デチョンも L 字型で二つに分けられている。No.5 も現在は商 業専用 (食堂) として使用されており、その平面形態は $\mathrm{H}$ 字型であ るが、大邱市が発行した 1975 年の航空写真を見ると東側に連続す る棟があったことが分かる。

これら三つの建物の敷地は（図 10 参照）、1911 年の地籍図によ れば隣接する No. 3 の敷地も含めて一体の敷地（鐘路 2 街 66 番、 78 番)であり、文献資料 18）19）よればNo.4 は 1890 年、No.5 は 1921 年、No. 2 は 1928 年に除・ビョンウォン氏の住宅として建設された ことが分かっている。その後、1933 年にすべてを李・ウォンマン氏 が自宅として購入し、No.4 をサランチェ、No.5 をアンチェに使用 し、南側の No.2 を息子の李・ドンチャン氏が使用していたことが 分かっている。さらに、1970 年代に真通地区を東西に横切る道路が 建設された際、No.5の敷地の一部が道路用地として買収され、1980 年代後半には No.5 の韓屋の東側の棟だけが解体されて、 3 階建ての ビルに建て替わった。同時にNo.3 の韓屋も 1980 年代に社宅として 売却されている。その後、登記簿によると 1982 年には残された No.5 の西側部分が改修されて店舗として利用されており、1990 年に No. 4 が 2006 年には No.2 が店舗に転用され現在に至っている。

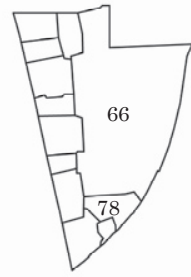

1911 年の地籍図 (番号は番地を示す。)

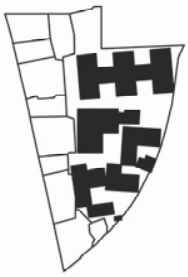

1920 年代の状況
図 10 鐘路 2 街 66 番と 78 番一帯の変遷過程

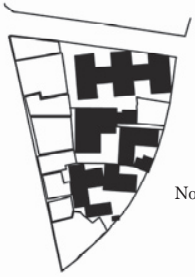

1970 年後半

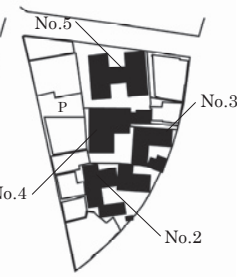

1980 年後半

\section{その他の韓屋 2 (No.7)}

No.7 は、現在商業専用 (食堂) として使用されており、その平面 形態は Ha JaeMyung ${ }^{8)}$ が示した平面類型とは異なるロの字型をし ている注 32 2)。この建物の敷地は、1911 年の地籍図によれば、隣接 するNo.6の敷地も含めて一つの敷地（鐘路 2 街 59 番）であったこ とが分かっているが当時の建物は残っていない（図 11 参照）。

登記簿によれば 1950 年代に敷地が分割され、現在の韓屋を含む 三つの韓屋が新たに建設されたことが分かる。

ただし、その北側の No.9 は L 字型であるが、文献資料 ${ }^{18)}$ によ れば朝鮮時代末期の建物であることが分かっており、1911 年の地籍 図には南一洞 140 番として一つの敷地でその後、敷地が分割された が、No.9の韓屋だけは壊されずに、現在まで維持されてきたものと 考えられる。

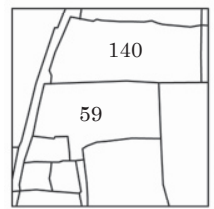

1911 年の地籍図 (番号は番地を示寸)

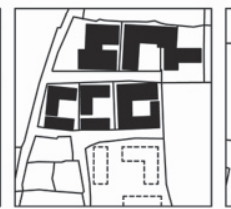

1950 年代の状況

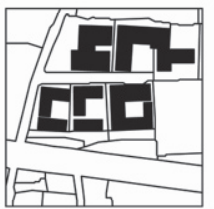

1970 年後半

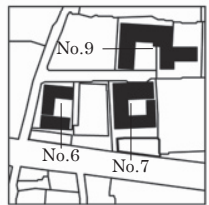

1980 年後半
図 11 鐘路 2 街 59 番の変遷過程
その他の韓屋 3（No.12、No.13）

No.12 は、現在住商併用（食堂）として使用されており、その平 面形態と内部構成は Ha JaeMyung ${ }^{8)}$ が示した L 字型韓屋と異なる 空間と廊下が存在する。文献資料 ${ }^{8}$ 8) によれば、この No.12の建物 は朝鮮時代末期に建設された韓屋の一部で、除・チョルギュン氏の 住宅のサランチェの部分であり、当時は南一洞 126 番〜 130 番まで の約 600 坪に韓屋があったことが分かっている(図 12 参照)。また、 登記簿によれば、1970 年後半南側を欴房に改修して店舗 (料亭) に 転用されたと記載されている注 33 )。

No.13 は、登記簿によれば、1949 年に建設された韓屋で、現在は 商業専用 (食堂) として使用されているが、当時の平面形態は $\mathrm{Ha}$ JaeMyung ${ }^{8)}$ が示した平面類型とは異なるロの字型であった。この 建物の敷地は（図 12 参照）、地籍図では鐘路 2 街 7 番の敷地であっ たことが分かっており、1970 年代後半敷地を東西に横切る道路の建 設とともに 1982 年には商業専用に用途変更が行われており、敷地 の南側にあったヘンランチェが解体され 1 階建ての物販店に建て替 わって現在に至っている。

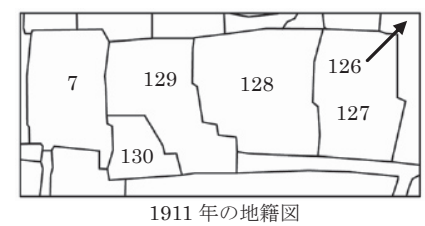

(番号は番地を示す。)

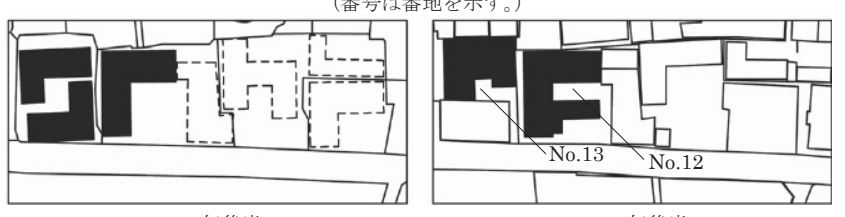

1970 年後半

1980 年後半

図 12 鐘路 2 街 7 番と 121 番の変遷過程

以上のことから、「その他」を除いた多くの韓屋が L 字型の平面 類型を示しており、1996 年に調查した邑城区域外の西城洞、仁橋洞 の都市型韓屋の状況 ${ }^{8)}$ とほぼ同じ傾向を示しているが、真通地区に 見られる「その他」に分類された韓屋は上記とは異なり、No.2、No.4 No.5、No.12 は朝鮮末期から 1920 年代までに建てられた大規模な 韓屋のアンチェやサランチェの一部であり、敷地が分割され、それ ぞれの敷地ごとに当時の韓屋がそのまま利用され使用されている分 割型韓屋注 34 4) であること、No.7、No.13 は 1940 1950 年代に新築 された改良韓屋であるが、その平面形態は口の字型で既往の研究 ${ }^{8)}$ と異なる類型であること、増築については「連続増築」「別棟増築」、 「マダン増築」、「内部改修」に分類でき、「連続増築」はほとんどの 平面類型に見られるが、「別棟増築」は「L字型」と「その他」だけ に見られ、「マダン増築」は商業用途だけに見られることなどが分か った。

\section{7 居住者意識}

居住者意識については、住居専用と住商併用の韓屋の居住者のア ンケートの結果を元に分析する注 35 )。

韓屋の各室については、「大変満足している」、少し満足している」、 「普通」、「やや不満」、「大変不満」の 5 段階で質問しており、各項 目を +2 から -2 の評価点とし、その平均值を満足度として、図 13、 
図 14 に示す。これを見ると、地区別では西門路がやや高いが、全 体的には満足度がマイナスとなっており、中でも倉庫や浴室の評価 が低いことが分かる。

また、居住年数が 20 年以上の居住者と比較して、20 年未満の居 住者の満足度は低く、中でも浴室の満足度が低い。

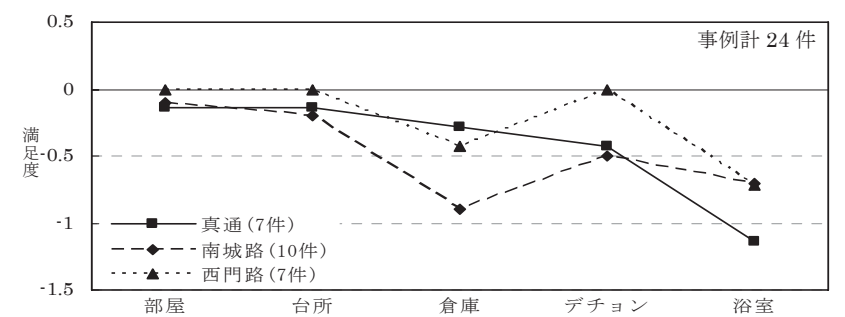

図 13 地区ごとの各室についての満足度（N:24）

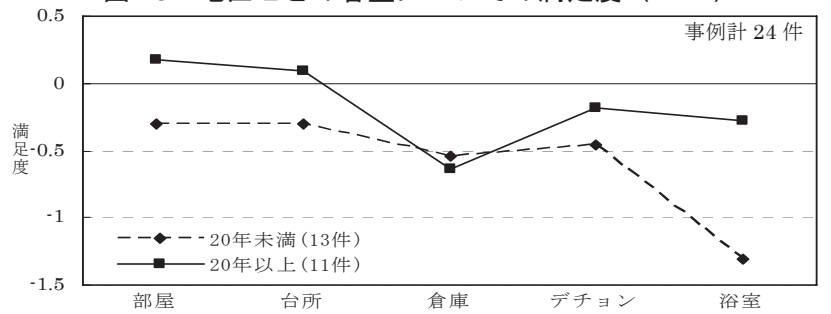

図 14 居住年数ごとの各室についての満足度（N:24）

韓屋の施設と性能については、「大変満足している」、満足してい る」、「少し満足している」、「普通」、「やや満足」、「不満」、「大変不 満」の 7 段階で質問しており、各項目を +3 から -3 までの評価点 とし、その平均值を満足度として、図 15、図 16 に示す。

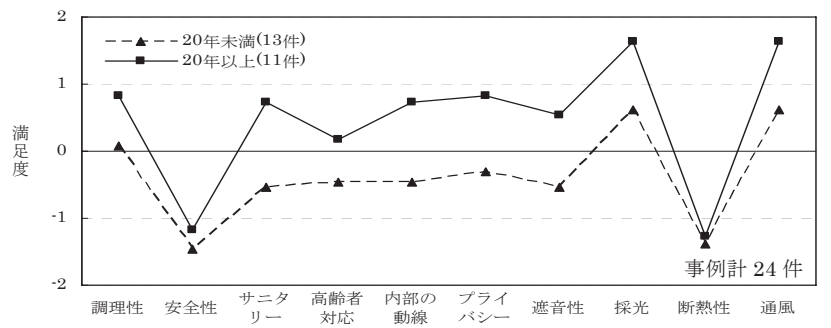

図 15 施設と性能の満足度（N:24）

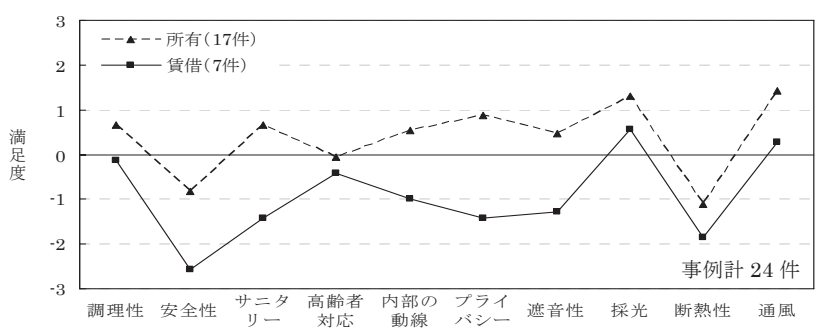

図 16 所有形態ごとの施設と性能の満足度（N:24）

韓屋の施設と性能について居住期間 20 年未満と 20 年以上の居住 者を比べると、全項目の満足度は 20 年未満の居住者が低く、所有 者に比べて賃借して生活している人の満足度が低い傾向にある。そ の中で採光、通風についての満足度は高い一方、安全性と断熱性に ついての満足度はいずれも低いことが分かる。

\section{8 街路環境と韓屋の保全に関する居住者意識}

街路環境と韓屋の保全に関する居住者意識については、商業専用 の韓屋の居住（使用）者も含めたアンケート結果を元に分析する。

\section{地区の街路環境に関する意識}

地区の街路環境については、「大変満足している」、満足している」、 「少し満足している」、「普通」、「やや不満」、「不満」、「大変不満」の 7 段階で質問しており、各項目を +3 から -3 の評価点とし、その平 均值を満足度として、図 17 、図 18 に示す。

街路環境のうち界隈性（伝統性、景観、親しみ、コミュニティ） に関する満足度は全体的に高く、特に真通地区で高い評価となって いる。一方、地区整備（防犯性、公園、駐車場、福祉施設）に関し ては、南城路地区や西門路地区の満足度はややプラスなっているが、 真通地区ではマイナス評価が多くなっている。

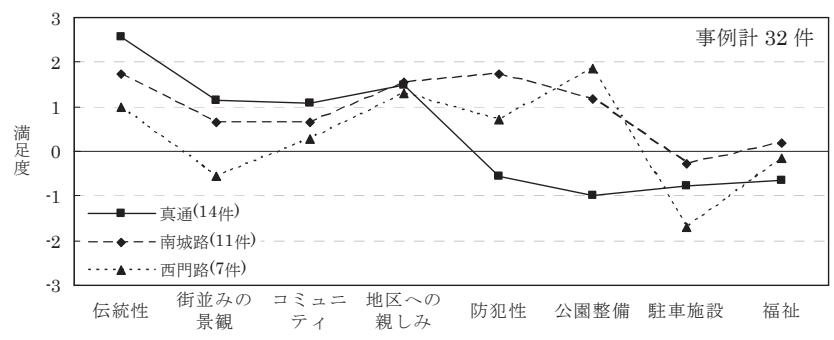

図 17 地区ごとの街並みについての満足度（N:32）

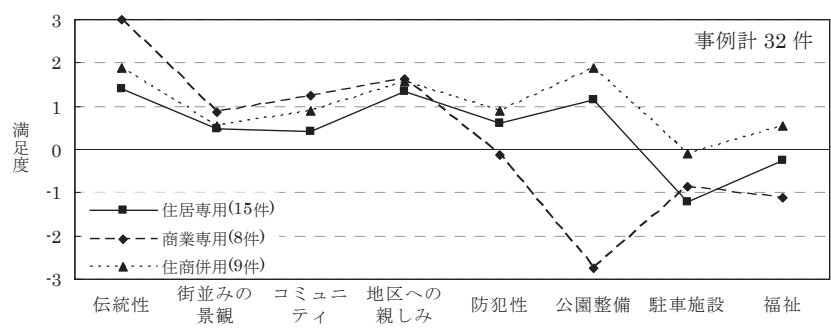

図 18 建物用途ごとの街並みについての満足度（N:32）

また、建物の使用用途ごとの街路環境についての満足度は、界隈 性に関して全般的に高く、伝統性に関しては商業用途の居住（使用） 者の評価が特に高い。また、地区整備に関しては公園整備、駐車場 に関して、商業用途の居住（使用）者の評価が低いことが分かる。

\section{韓屋保全に関する意識}

図 19 に韓屋居住（使用）者の韓屋保存に関寸る意識についての アンケート結果を示す。

これを見ると、韓屋保存の賛否については、商業専用で居住（使 用）している住民では賛成が多い一方、住居専用、住商併用の居住 者では反対が多い。また、韓屋の賃借よりも所有者に反対が多い。 また、韓屋保存地区指定の賛否に関しては商業専用の居住（使用） 者の賛成はさらに多くなっている一方で、居住者は反対の方が多い。

また、最近実施されている大邱市中区主催の歴史街路ツア一注 36$)$ については、住商併用の居住者も含めて約半数が「良い」と回答し ている。これらことは、韓屋の居住者や使用者にとってこの地区の 歴史的な価值を高く評価していることが伺える。また、将来にこの 地区を再開発することの賛否については全体として賛成の方が多く、 住居専用の居住者でも賛成が反対よりも多く、賃借者よりも所有者 の方が賛成している割合が高いこと、このことはアンケートにも「再 
開発の機会があれば高く売却できる」ことや「韓屋を維持していく のは経済的に難しい」ことなどの指摘が見られ、邑城地区の韓屋所 有者が抱える課題を示している。
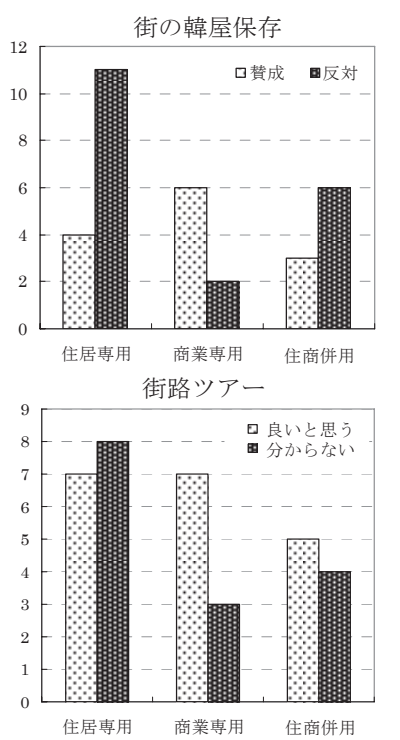

街の韓屋保存

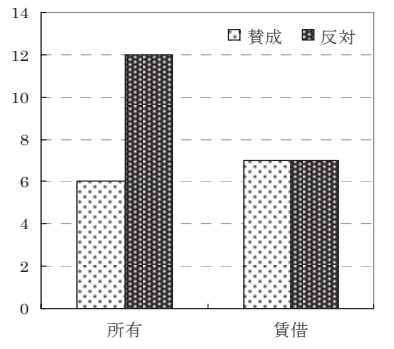

図 19 保全に関する意識（N:32）

\section{4. 結論}

本研究では大邱市邑城区域（城内一洞〜城内三洞）にわずかに残 る都市型韓屋が現在どのように維持、転用されているのかの実態を 把握するとともに、韓屋の居住（使用）者への意識調査を実施し以 下の結果を得た。

1. 邑城区域内に残存する都市型韓屋は 50 件あり、住居専用として 使用されているものが $46 \%$ （23 件）、商業専用 $18 \%$ (9 件)、住商 併用 $20 \%$ (10 件)、空き家 $16 \%$ （8 件）である。

2. 調査対象都市型韓屋において商業専用に転用されている韓屋の 約 8 割（7 件）が 1990 年以降に事業者が韓屋所有者から建物を借 りて営業していること、一方住宅として維持されている韓屋の約半 数（7 件）は父母世帯から継承されており、現居住者の約 4 割（8 件）が 30 年以上ここに居住している。

3. 住宅として使用されている韓屋の家族人数は、一人暮らしの世 帯が約 3 割（6 件）で、家族人数が 3 人以下が $75 \%$ （18 件）を占 めており、世帯主の年齢は 60 歳代以上が $67 \%$ （16 件）を占め、全 部又は一部が住宅として使用されている韓屋においては家族の少人 数化、高齢化が進んでいる可能性がある。

4. 現存する韓屋の用途と面積は真通地区の韓屋が比較的大きく、 店舗に転用されているものが多い一方、その他の地区は住宅として 維持されているものが多い。
5. 大邱市邑城区域内の都市型韓屋は日帝時代が終わった 1945 年以 降に多くが建設され、1980 年代からの急速な都市化とともに増改築、 転用が増えたものと考えられる。

6. 邑城区域内における都市型韓屋は、Ha JaeMyung ${ }^{8)}$ が 1996 年 に調查した邑城区域外の西城洞、仁橋洞の都市型韓屋とほぼ同様の 類型を示しているが、真通地区に見られる 7 件は異なる類型で、そ のうち 2 件はそれとは異なるロの字型を示しており、残りの 5 件は 朝鮮末期から 1920 年代までに建てられた大規模な韓屋のアンチェ やサランチェの部分であり、敷地が分割されそれぞれの敷地ごとに 当時の建物がそのまま利用され使用されている分割型韓屋であるこ とが分かった。

7. 増改築に関しては「連続増築」が 14 件、「別棟増築」が 13 件、 「マダン増築」が 4 件で「内部改修」は 23 件であり、「連続増築」 はほとんどの類型に見られるが、「別棟増築」はＬ字型と「その他」 だけに見られ、「マダン増築」は商業専用にだけに見られる。

8. 都市型韓屋の満足度は、各室について全体的に低く、居住期間 が 20 年未満の居住者の評価が低いこと、施設と性能に関しても、 居住期間 20 年未満の居住者の満足度が低く、賃借して生活してい る人の満足度が低い傾向になる。特に安全性と断熱性について評価 が低い一方、採光と通風についての評価は高い。

9. 街路環境についての評価は、伝統性、景観、コミュニティ、地 区への親しみなどの界隈性に関する評価は全般的に高く、特に商業 用途の使用者の満足度が高い。一方、防犯性、公園整備、駐車場な ど地区整備に関する評価は全般的に低く、特に真通地区の公園整備 に対する満足度が低い。

10. 邑城区域内で都市型韓屋を住宅として維持している住民にとっ ては、この地区の街並みや歴史的な価值を評価しているが韓屋保存 には否定的な回答が多い。一方、韓屋を店舗に転用して使用してい る住民はこの地区の伝統性や歴史的価值を高く評価しており、保存 地区に指定されることに賛成する回答が多い。

以上は本研究によって得られた知見であり、これは今後当該地区 の再整備と韓屋保全のための手がかりになるものと思われる。特に 大邱邑城地区における今後の市街地整備と韓屋保全活用の可能性は 地区によってその状況が異なり、商業用途に転用された韓屋が多く 見られる真通地区では、商業使用者の伝統性や街並み保存に対する 意識が高く、韓屋保存にも肯定的な意見が多いことから、収益が見 込め、所有者の賛意が得られれば街路ツアーや韓屋観光を今後の市 街地整備における特色としての活用可能性が示唆できる。一方、住 居専用又は住商併用の韓屋が多く見られる南城路や西門路では居住 者の少人数化、高齢化の傾向もあり、韓屋保存には否定的な意見が 多いが、ただ住民意識では伝統性や地区への親しみが高いことから、 現施設一の不満が多い「安全性」や「断熱性」「浴室設備」などの 改善を支援するシステムの構築などが当該地区における韓屋の保存 活用の契機になるものと考える。

ただ、今回の論文では大邱市邑城区域に限って調查分析を進めた が、中心市街地の開発と伝統的住宅の保存に関する問題は、大邱市 と同様に韓国の他の都市や近年の経済発展が著しい新興国において も考えられることから、今後は他の地域と比較を含めて、分析を進 めていきたい。 
注

注 1）官府とその市街地の周りに築いた城壁。大邱邑城は、周り $2.7 \mathrm{Km}$ 、高 さ $5 \mathrm{~m}$ 、厚さ $8 \mathrm{~m}$ の石城壁であった ${ }^{18)}$ 。

注 2) 大邱慶北研究所の Kim TaYeul ${ }^{1)}$ によれば、大邱市中心市街地の衰退 原因について、第 1 位が常住人口の減少、第 2 位が建物の老朽化と述 ベており、夜間人口の減少による犯罪発生の問題についても指摘して いる。

注 3) 大邱中部警察署の犯罪統計 ${ }^{2)}$ によれば、中区の犯罪発生件数は 2009 年 で 1815 件、 2010 年で 2445 件、2011 年で 2874 件と増加傾向にある。

注 4）朝鮮時代末期の 1876 年の日韓修好条約以降を開化期と言う ${ }^{7)}$

注 5） 1910 年日韓合併から 1945 年までを日帝時代と呼ぶ

注 6）全州市では 1980 年代頃まで韓屋が建設されている ${ }^{131}$

注 7）母屋を意味する。伝統韓屋の中では女性と子供が使用する建物

注 8）朝鮮時代に嶺南地方を監督する官宁

注 9）現在の慶尚南道・慶尚北道、釜山広域市、蔚山広域市、大邱広域市を 指している地域

注 10）木造瓦莫家屋は、都市型韓屋以外に日式住宅や西洋住宅なども含まれ ることから、実踏調査を行い、屋根の形状や間取りの特徵、使用材料 などによって「1.2 都市型韓屋の定義」に従って選定した。

注 11） $\mathrm{F}$ 検定によって母集団の分散を推定し、それぞれの平均值について $\mathrm{t}$ 検定を実施した結果、いずれも $\mathrm{p}>0.05$ となり $5 \%$ 水準の有意差は見ら れなかった。

注 12）現場調査と文献資料を元に筆者が作成した。

注 13）現場調査と文献資料を元に筆者が作成した。

注 14）韓国の住宅における敷地の境界線を囲む塀に設置されている主の出入 ロを大門と言う。

注 15）パルジャック屋根と小屋組みの形状。パルジャック屋根は軒先の形状 が異なるが日本の入母屋屋根と同種の形状である (図は筆者が自筆)

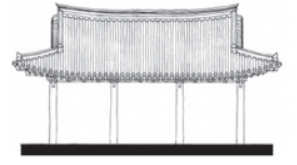

パルジャック屋根

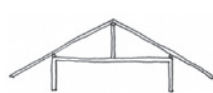

3 樑
注 16）韓屋の中央にある広い板の間

注 17) 台所

注 18）敷地内の中庭

注 19）主人が居住するところでブオック (台所) 隣の部屋

注 20）現場調査と文献資料を元に筆者が作成した。

注 21）デチョンを挟んでアンバンの向かいにある部屋（図は筆者が自筆）

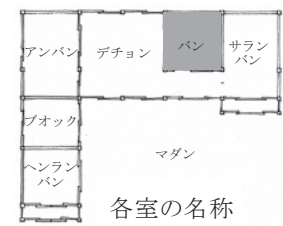

注 22）主人の居間を兼ねた客間、都市型韓屋では結婚した長男夫婦の部屋と することが多い

注 23）大門の隣の部屋

注 24）カマドや特別に設けられた焚口で火を焚いて暖めた空気（煙）を床下 に配した煙道に送り、床を暖める暖房方式

注 25）味噌の盇と醬油盇などの置き場

注 26）真通地区は東側に隣接する繁華街（東城路地区）に近いことから商業 利用が多くなっている一方で、南城路地区と西門路地区は東城路地区 から離れているため商業利用が少ないことが要因である可能性がある。

注 27）韓屋では、建設時に上棟樑に建設年度を記載する習慣があった。

注 28）ただし、朝鮮末期時代から日帝時代の 6 件の改築履歷については、登 記簿に記載されていないため、関係者のヒアリングに頼った。

注 29) Ha JaeMyung ${ }^{8)}$ の研究では、不完全コの字型の下位分類を「南向き」 と「東向き」に分けているが、本論文では該当件数が少ないため上位 分類によって区分し分析を行った。

注 30）伝統韓屋の中で主人の居間と客間として使用寸る建物

注 31）門屋、伝統韓屋の中で大門とその両方に部屋がある建物

注 32) コの字型とロの字型の区別の方法として、屋根が連続していない場合、 屋根の途切れている部分がマダンの一部として利用できる程度の空間 があいていない場合はロの字型と判断した。
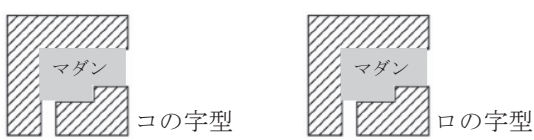

注 33） 2011 年には建物が解体され駐車場になっている。

注 34）アンチェだけの空間を主人が使用し、その他の建物を分割して別の 住宅として使用した韓屋を言う。

注 35）日常的にその場所で居住・生活しているわけではない被験者（ここで は商業専用）を除いて分析した。

注 36) 大邱市中区、「路地探訪」ホームページ（韓国語）

http://gu.jung.daegu.kr/culture2/place/list.html?p_id=2-2\&s=\&s1=r der\&o1 $=\operatorname{asc} \& m o l=\& p=2 、 2011$ 年

\section{参考文献}

1）Kim TaYeul：大邱市都心活性化政策ワークショップ，大邱慶北研究院， pp101 104, 2006

2）大邱中部警察署：年度別犯罪統計， 2012

3）西村幸夫 : 都市保全計画，歴史・文化・自然を活かしたまちづくり，東京 大学出版会, pp681 695, 2004

4）ソウル特別市韓屋文化課：北村文化センター，ホームページ（日本語） http://bukchon.seoul.go.kr/jap/index.jsp, 2011.9.5 に参照

5) 大邱市中区 : 特化街探訪, ホームページ (日本語)

http://www.gu.jung.daegu.kr/japanese/sub3_1. html, 2011.9.5 に参照

6) 韓国建築歴史学会: 韓国建築史研究 1 - 分野と時代, バルオン, pp193 235, 2003.5

7) Yoon JaeWoong : A Study on the Characteristics of the Spatial Composition at the Modern Korean Houses after the Time of Enlightenment in Daegu Province, 大韓住居学会論文集, 第 14 巻 6 号, pp87 93, 2003.12

8) Ha JaeMyung, Sohn SeiKwan, Yang WooHyun, Park ChanDon, Park Sun Kyung : A Study on the Plan Types of Urban Traditional Housing - the case of Seo-sung dong, In-geo dong, 大韓建築学会論文集，第 12 巻 5 号, pp75 83, 1996.5

9) Song InHo : 都市型韓屋の類型研究, ソウル大学博士論文, 1993

10) Park CheolJin, Jeon BongHee : The Socio-economical Background and Characteristics of Plan of Urban Traditional Housing in Seoul of 1930s, 大韓建築学会論文集，第 18 巻 7 号，pp95 106, 2002.7

11）無涯建築研究所編：嘉会洞韓屋保存地区実測調査報告書, ソウル大学, 1985

12) Song InHo : A Study on the Plan Types of Urban Traditional Housing the case of Ga-hoe dong traditional residential district，大韓建築学会 論文集，第 4 巻 1 号，pp61 68，1988.2

13) Sohn SeiKwan, Ha JaeMyeong, Yang WooHyun, Yang YongJung : A Study on the Plan-Types of Urban Traditional Housing in CHOENJU, 大韓建築学会論文集，第 12 巻 7 号，pp29 38，1996.7

14) Song InHo, Kim YoungSoo, Cho EunJoo : A study on the Changes in form and spatial uses of Urban Hanok in Bukchon, Seoul, 建築歴史 研究，第 18 巻 2 号, pp47 63, 2009.4

15) Ha JaeMyung, Hwang BoBong: The Formation and Change of Traditional Urban Residential Areas - In case of Sosongdong, Junggu, Taegu City，大韓建築学会論文集，第 11 巻 12 号，pp89 100，1995.12

16）槙鮮化，鳴海邦碩，澤木昌典：韓国・大邱市の戸建て住宅地における個 別建替えによる屋外空間の変化に関する研究, 日本建築学会計画系論文 集，第 612 号，pp79 85，2007.2

17) Yeo MiNa, Yoon JaeWoong : A study on the realities of composition and utilization for Green Space of the urban traditional residences nearby downtown of Taegu，大韓住居学会学術発表大会論文集，pp57 62， 1997.11

18) 街文化市民連帯: 大邱新択里志, 図書出版 Book Land, pp242 249, 2007.3

19）大邱中区街づくり支援センター：大邱近代建築物オープンハウス，大邱 市中区, pp24 37, 2010.10

20) Lee HaeKyung, Kang GyoungHo : A Study on the Changes of Spatial Structure of Korean Traditional Housing in Urban Context, 大韓住居 学会論文集，第 18 巻 4 号，pp69 78，2007 